\title{
Correlation between serum amyloid- $A$ and serum levels of proinflammatory cytokines in patients with Behçet's disease
}

\author{
OM Lucherini ${ }^{*}$, G Lopalco², L Cantarini ${ }^{1}$, A Vitale ${ }^{1}$, C Rotondo², A Lopalco ${ }^{3}$, R Talarico ${ }^{4}$, M Galeazzi ${ }^{1}$, G Lapadula², \\ F lannone ${ }^{2}$
}

From 8th International Congress of Familial Mediterranean Fever and Systemic Autoinflammatory Diseases Dresden, Germany. 30 September - 3 October 2015

\section{Introduction}

Behçet's disease (BD) is an inflammatory disorder of unknown aetiology, unanimously recognized as both autoimmune and autoinflammatory disease. Indeed many of its classical manifestations overlap with those of monogenic autoinflammatory disorders. Clinically disease is characterized by multiple organ involvement, in particular by the "triple symptom complex", consisting of recurrent oral aphthosis, genital ulcers and recurrent bilateral uveitis. The abnormal activation of either innate and adaptive immunity, triggered by some microbial agents in genetically predisposed individuals, with consequent interaction of both $\mathrm{T}$ lymphocytes and activated neutrophils would seem to be involved in the disease onset. Therefore multiple cytokines may contribute to the pathological scenario of BD playing a pivotal role in the occurrence of the clinical manifestations.

\section{Objectives}

To determine serum levels of IL-8, IL-18, IFN- $\alpha 2 a$, IL-6, IFN- $\gamma$, CXCL10, CXCL11, CXCL9 and serum amyloid-A (SAA) concentration in patients with $\mathrm{BD}$, in comparison to healthy controls $(\mathrm{HC})$, and to correlate their concentration with the status of disease activity.

\section{Materials and methods}

78 serum samples were collected from 58 BD patients ( 28 males, 30 females, mean age $44.7 \pm 12.2$ years). Serum cytokine levels of IL-8, IL-18, IFN- $\alpha 2 a$, IL-6, IFN- $\gamma$, CXCL10, CXCL11 and CXCL9 were determined using a

${ }^{1}$ University of Siena, Siena, Italy

Full list of author information is available at the end of the article multiplex bead analysis as well as SAA was assessed by Enzyme linked-immunosorbent assay.

\section{Results}

In BD patients serum concentrations of IL-8 ( $\mathrm{p}=0.0001)$, IL-18 $(\mathrm{p}=0.0058), \quad$ IFN- $\alpha 2 \mathrm{a} \quad(\mathrm{p}=0.0181)$ and IL-6 $(\mathrm{p}=0.0233)$ were significantly higher than in HC. When $\mathrm{BD}$ patients were divided into active and inactive group, IL- 8 and IL-18 resulted higher in both active- $(\mathrm{p}=0.0001$ and $\mathrm{p}=0.012$ respectively $)$ and inactive- $\mathrm{BD}(\mathrm{p}=0.0001$ and $\mathrm{p}=0.0128$ respectively) than in $\mathrm{HC}$, while IFN- $\alpha 2 \mathrm{a}$ $(p=0.0141)$ and IL-6 $(p=0.0332)$ serum levels were significantly higher in active-BD than HC. Moreover, CXCL11 ( $\mathrm{p}=0.0154)$ serum concentrations were significantly lower in inactive-BD than HC. We also compared serum cytokine profiles between BD patients with SAA serum levels $\leq 20 \mathrm{mg} / \mathrm{L},>20 \mathrm{mg} / \mathrm{L}$ and HC. Interestingly, we observed that BD patients with SAA $>20 \mathrm{mg} / \mathrm{L}$ showed higher levels of inflammatory markers than $\mathrm{HC}$. Among these cytokines, IL-18, IFN- $\alpha 2$ a and IL- 6 were higher in BD group with SAA $>20 \mathrm{mg} / \mathrm{L}$ than $\mathrm{HC}$, whereas IL-8 and CXCL9 levels were higher than in patients with SAA $\leq 20 \mathrm{mg} / \mathrm{L}$ and $\mathrm{HC}$.

\section{Conclusions}

BD patients exhibit elevated levels of specific inflammatory mediators, especially during active disease periods and in those patients with SAA serum levels $>20 \mathrm{mg} / \mathrm{L}$, thus suggesting a possible role of SAA in the induction of $\mathrm{BD}$ inflammatory manifestations. 
Submit your next manuscript to BioMed Central and take full advantage of:

- Convenient online submission

- Thorough peer review

- No space constraints or color figure charges

- Immediate publication on acceptance

- Inclusion in PubMed, CAS, Scopus and Google Scholar

- Research which is freely available for redistribution

Submit your manuscript at www.biomedcentral.com/submit
C Biomed Central 